\title{
Physiological characteristics of two accessions of moringa (Moringa oleifera Lam.) at different planting sites in Madura
}

\author{
Catur Wasonowati ${ }^{1}$, Endang Sulistyaningsih ${ }^{2 *}$, Didik Indradewa ${ }^{2}$, and Budiastuti Kurniasih ${ }^{2}$ \\ ${ }^{1}$ Study Program of Agroecotechnology, Faculty of Agriculture, Trunojoyo Madura University \\ Jln. Raya Telang, Kamal, Bangkalan-Madura, Indonesia \\ ${ }^{2}$ Department of Agronomy, Faculty of Agriculture, Universitas Gadjah Mada \\ Jln. Flora no. 1, Bulaksumur, Sleman, Yogyakarta 55281, Indonesia \\ *Corresponding author: endangsih@ugm.ac.id
}

Received: 03 ${ }^{\text {rd }}$ July 2019; Revised: 30 ${ }^{\text {th }}$ December 2019; Accepted: $13^{\text {th }}$ May 2020

\section{Keywords:}

Accession, Moringa oleifera, physiology, site

\begin{abstract}
Moringa plants grow in Sumenep with semi-intensive planting at the moor and several planting sites. Sumenep is one of the districts in Madura Island, which is categorized as a dry area based on the Oldeman climate classification. Based on the color of the leaf stalk, moringa plants growing in Sumenep area are categorized as green and purple moringa. The study aimed to examine the differences in physiological characteristics of two accession of moringa plants at different planting sites in Madura. The study was arranged in Oversite Sub-sampling Design with planting site as first factor consisting of Bluto with E5 climate type and Guluk-guluk with D3 climate type. Meanwhile, the second factor was the type of moringa consisting of moringa with green and purple leaf stalks. The results showed that the different planting sites represented the differences in environmental elements, which influenced the physiological characteristics of moringa plants. Based on the observation in September 2016, moringa plants with green stalks planted in Guluk-guluk had high ANR content. The stomatal opening on moringa leaves with green stalks was larger than that on moringa plants with purple stalks, whereas ANR content in green-stalked moringa was lower than in the purple-stalked ones. Meanwhile, in February 2017, the purple-stalked moringa plants planted at Bluto had the highest transpiration rate and proline content compared to the others.
\end{abstract}

\section{INTRODUCTION}

Moringa (Moringa oleifera Lam.) plants mainly grow in tropical and subtropical regions. This plant is able to survive in poor soil nutrient conditions. Moringa trees can grow quickly and withstand drought (Luthfiyah, 2012). Sumenep is included in the category of tropical and dry region in Indonesia, which has D and E climate type as Bluto District has E5 climate type and Guluk-guluk District has D3 climate type (Badan Pusat Statistik Kabupaten Sumenep, 2014).

Moringa plants grow in Madura Island with semiintensive planting at the moor and several planting sites. Based on the color of the leaf stalks, moringa plants growing in Sumenep consist of two accessions, which are green-stalked and purple-stalked moringa (Barselia et al., 2014). Moringa cultivation in several planting sites was reported to vary geographically or agro-ecologically in increasing nutrient composition in various organs of moringa plants. Khaerana et al. (2008) stated that plants experiencing drought stress tried to make physiological changes such as maintaining turgor pressure or osmotic adjustment as a form of adaptation. Plants have an adaptive mechanism to face biotic and abiotic stresses. This includes the mechanism of photosynthesis, osmoregulation, and antioxidant enzymes (Liu et al., 2004). 
Water shortages result in abnormal physiological and morphological processes, causing the plant growth to be stalled or stopped. So far, there has not been much information about the physiological and biochemical properties of the green-stalked and purple-stalked moringa plants planted at different growing environmental conditions in Madura. Therefore, this study was conducted to examine the physiological characteristics of different accessions of moringa plants at planting sites with different environmental conditions.

\section{MATERIALS AND METHODS}

The research was conducted in two locations (Bluto and Guluk-guluk Subdistrict) in Sumenep Regency, Madura, East Java. The analysis of physiological characteristics was carried out at the Laboratory of Agroecotechnology, Faculty of Agriculture, University Trunojoyo, Madura. Observations were performed in September 2016 and February 2017.

The experiment was arranged in Oversite Subsampling Design. The first factor was the planting site consisting of Bluto (E5 climate type, semi-intensive planting in the moor and yards) and Guluk-guluk (D3 climate type, non-intensive planting in the moor and home yards), while the second factor was the accession of moringa plants consisting of greenstalked and purple-stalked moringa plants. Of the two factors, four treatment combinations were obtained for each plot replicated five times, so that there were ten experimental plots with a size per plot of about $200 \mathrm{~m}^{2}$.

\section{Physiological characteristics of moringa plants}

Observations were made twice, which were during the peak of the dry season in September 2016 and during the peak of the rainy season in February 2017.

\section{Observation of the transpiration rate and period using cobalt chloride method}

Transpiration rate was measured by using the time needed to change the cobalt chloride paper from blue to pink (Akunda et al., 1981). Dry cobalt chloride paper will turn pink when exposed to moisture, including those from transpiration. The faster the transpiration rate, the shorter the time needed to change color. The measurement was carried out between $11 \mathrm{AM}-2 \mathrm{PM}$ on the $2^{\text {nd }}$ to $4^{\text {th }}$ leaves, which had opened fully and were exposed to direct sunlight. The paper was placed under 1 $\mathrm{mm}$-thick hard transparent plastic with a size of 2 $\mathrm{cm} \times 2 \mathrm{~cm}$ on the bottom surface of the leaf, pinned with a paper clip. The number of samples for each plant was three samples.

\section{Observation on stomata}

The method used is the replica method. The surface of the leaf samples was cleaned, brushed with nail polish, and left for 10 minutes to dry. The dry spread was insulated and flattened, then stuck slowly to the glass object. The observation of the number of stomata per field of view using a microscope with the same magnification (40×) (Haryanti, 2010).

\section{Proline content}

Proline content was determined by the method developed by Bates et al. (1973). Leaf samples used were the perfectly developed leaves. A total of $0.5 \mathrm{~g}$ of leaves was extracted in $10 \mathrm{~mL}$ of $3 \%(\mathrm{w} / \mathrm{v})$ sulfosalicylic acid and then filtered with filter paper. As much as $2 \mathrm{~mL}$ of filtrate was reacted with $2 \mathrm{~mL}$ of ninhydrin acid solution and $2 \mathrm{~mL}$ of glacial acetic acid in a test tube for 1 hour at $100^{\circ} \mathrm{C}$, then the reaction process was terminated in "ice bath". This mixture was then extracted with $4 \mathrm{~mL}$ of toluene and shaken vigorously using a "test tube stirrer" for $15 \mathrm{~s}$ to $20 \mathrm{~s}$. Then the absorbance was measured at $520 \mathrm{~nm}$ with a SHIMADZU 160A spectrophotometer (Novenda, 2016). The proline content then was calculated using the following formula:

Proline content $=(64.36 \times$ absorbance $+(-5.29)) \times 0.34$

$$
=\mu \mathrm{mol} \text { proline. } \mathrm{g}^{-1}
$$

\section{Relative moisture content (RMC)}

$\mathrm{RMC}$ was measured by weighing the fresh weight of 5 compound leaf samples from each plant. After that, the samples were immediately immersed in distilled water for 24 hours to obtain turgid weight. The samples then were dried in an oven to get dry weight. Relative moisture content was calculated by the following formula (Islami and Utomo, 1995):

$$
\mathrm{RMC}=\frac{\text { fresh weight }- \text { dry weight }}{\text { turgid weight }- \text { dry weight }} \times 100 \%
$$




\section{Data analysis}

The data obtained were analyzed using analysis of variance according to the Oversite Sub-sampling Design at $5 \%$. The data showing significant differences between treatments were then tested with Duncan Multiple Range Test at 5\%.

\section{RESULTS AND DISCUSSION}

\section{The condition of research location}

The research was conducted in two sub-districts, namely Bluto and Guluk-guluk Subdistrict, Sumenep Regency, which is a region that has a population of two accessions of moringa plants (green and purple leaf stalks).

The results of soil analysis in both locations showed that the actual water content in Bluto and Guluk-guluk was $13 \%$ and $18 \%$, respectively, while the $\mathrm{pH}$ was neutral, which was 7.34 and 7.24 , consecutively. The $\mathrm{N}$ content in both locations was low (0.19\% in Bluto and $0.11 \%$ in Guluk-guluk), and the P content was $11.7 \mathrm{mg} . \mathrm{kg}^{-1}$ in Bluto and 8.33 mg.kg-1 in Guluk-guluk. Meanwhile, the K content in Bluto and Guluk-guluk was in the moderate (0.45me per $100 \mathrm{~g}$ ) and low category (0.19 me per $100 \mathrm{~g})$, respectively.

The micro climate observed included an average air temperature of $34^{\circ} \mathrm{C}$, air humidity of $61.94 \%$ to $63.39 \%$ (Bluto) and $57.74 \%$ to $59.50 \%$ (Gulukguluk), and soil temperature of $30.76^{\circ} \mathrm{C}$ to $31{ }^{\circ} \mathrm{C}$ (Bluto) and $29.61{ }^{\circ} \mathrm{C}$ to $30.02{ }^{\circ} \mathrm{C}$ (Guluk-guluk) (Table 1). Based on the data, Bluto is drier, but the soil fertility rate is slightly higher than that in Guluk-guluk. Meanwhile, the micro climate in both locations is almost the same.

\section{Stomata}

Data in Table 2 show that there was no interaction effect between the planting site and the accession of moringa on the stomatal density and opening. According to the observations in September 2016, moringa plants in Bluto had lower stomatal density compared to the plants in Guluk-guluk during the

Table 1. The microclimate in Bluto and Guluk-guluk Sub-district

\begin{tabular}{lcc}
\hline Variable & Bluto & Guluk-guluk \\
\hline Air temperature $\left({ }^{\circ} \mathrm{C}\right)$ & $34.27-34.52$ & $34.11-34.30$ \\
Air humidity $(\%)$ & $61.94-63.39$ & $57.74-59.50$ \\
Soil temperature $\left({ }^{\circ} \mathrm{C}\right)$ & $30.76-31.00$ & $29.61-30.02$ \\
\hline
\end{tabular}

Table 2. Stomatal density and the width of stomata opening of different accessions of moringa plants planted at different sites

\begin{tabular}{|c|c|c|c|c|}
\hline \multirow[b]{2}{*}{ Treatment } & \multicolumn{2}{|c|}{$\begin{array}{l}\text { September } 2016 \\
\text { (Dry season) }\end{array}$} & \multicolumn{2}{|c|}{$\begin{array}{l}\text { February } 2017 \\
\text { (Rainy season) }\end{array}$} \\
\hline & $\begin{array}{c}\text { Stomatal } \\
\text { density } \\
\left(\mathrm{mm}^{2}\right)^{-1}\end{array}$ & $\begin{array}{c}\text { The width of } \\
\text { stomata } \\
\text { opening }(\mu \mathrm{m})\end{array}$ & $\begin{array}{l}\text { Stomatal } \\
\text { density } \\
\left(\mathrm{mm}^{2}\right)^{-1}\end{array}$ & $\begin{array}{c}\text { The width of } \\
\text { stomata } \\
\text { opening }(\mu \mathrm{m})\end{array}$ \\
\hline \multicolumn{5}{|l|}{ Planting sites } \\
\hline Bluto & 191.01 b & $2.77 \mathrm{a}$ & $252.87 \mathrm{a}$ & $4.18 \mathrm{a}$ \\
\hline Guluk-guluk & 229.41 a & $2.89 a$ & 257.66 a & $4.32 \mathrm{a}$ \\
\hline \multicolumn{5}{|l|}{ Stalk color } \\
\hline Green & $210.91 p$ & $3.04 p$ & $269.34 p$ & $4.19 p$ \\
\hline Purple & $209.52 p$ & $2.61 \mathrm{q}$ & $241.18 p$ & $4.31 \mathrm{p}$ \\
\hline CV (\%) & 15.23 & 11.71 & 15.68 & 12.23 \\
\hline Interaction & $(-)$ & $(-)$ & $(-)$ & $(-)$ \\
\hline
\end{tabular}

Remarks: Means followed by the same letters in the same column were not significantly different according to Duncan's multiple range test at 5\%. (-): no interaction between treatments. 
peak of the dry season. Meanwhile, there was no significant difference in the the stomatal density between the accessions of moringa. The width of the stomata opening of moringa plants in Bluto was not significantly different from those in Guluk-guluk, but there was a significant difference observed between the accessions of moringa. According to the observations in February 2017, there was no significant difference in the stomatal density and opening of moringa plants either between the accessions or the planting sites during the peak of the rainy season.

The stomatal density of moringa plants in Gulukguluk was higher than that of plants in Bluto since the actual moisture content in Guluk-guluk was higher than in Bluto. Stomatal density was an indicator of the number of stomata found in a particular leaf area. The high stomatal density indicates that the number of stomata able to carry out transpiration is high. The width of the green-stalked moringa stomata opening was wider than that of the purple ones.

This was presumably because the green-stalked moringa plant was more resistant to drought than the purple one.

\section{Photosynthesis rate measured with bromothymol blue (BTB)}

Data in Table 3 show that there was no interaction effect between the planting sites and the accessions of moringa plants on the photosynthesis rate measured with the BTB method in September 2016, during the peak of the dry season, and in February 2017, during the peak rainy season.

The observations in September 2016 and February 2017 showed that the planting sites and accessions of moringa did not affect the rate of photosynthesis. Photosynthesis rate is related to the chlorophyll content. Photosynthesis is a metabolic process, in which plants synthesize organic compounds from organic raw materials in the presence of sunlight. Photosynthesis in plants is influenced by sunlight, which includes radiation and the intensity of sunlight. This result was because plants that grow in Bluto with low actual water content will cover stomata to maintain leaf water content, thereby resulting in a decrease in internal $\mathrm{CO}^{2}$ that limits photosynthesis (Herrera, 2013). Increased photosynthesis rate occurs when light intensity increases. When the light intensity is low, the rate of photosynthesis decreases. Each plant species has an optimal range of light intensity for photosynthesis in increasing growth and production (Anni et al., 2013).

\section{Period and rate of transpiration measured with cobalt chloride}

Table 4 show that there was no interaction effect between the planting sites and accessions of moringa on the period and rate of transpiration measured with cobalt chloride paper in September 2016, but there was interaction effect observed in February 2017. In September 2016, there was no

Table 3. Photosynthesis rate of different accessions of moringa plants planted at different sites

\begin{tabular}{lcc}
\hline \multirow{2}{*}{ Treatment } & \multicolumn{2}{c}{ Photosynthesis rate $\left(\mathrm{mg} \cdot \mathrm{dm}^{-2} \cdot \mathrm{h}^{-1}\right.$ ) } \\
\cline { 2 - 3 } & $\begin{array}{c}\text { September 2016 } \\
\text { (Dry season) }\end{array}$ & $\begin{array}{c}\text { February 2017 } \\
\text { (Rainy season) }\end{array}$ \\
\hline Planting sites & $30.22 \mathrm{a}$ & $2.169 \mathrm{a}$ \\
Bluto & $41.36 \mathrm{a}$ & $3.978 \mathrm{a}$ \\
Guluk-guluk & & $3.412 \mathrm{p}$ \\
\hline Stalk color & $42.96 \mathrm{p}$ & $2.735 \mathrm{p}$ \\
Green & $28.63 \mathrm{p}$ & $(-)$ \\
Purple & 28.08 & $(-)$ \\
\hline CV (\%) & & \\
\hline Interaction & & \\
\hline Remarks: Means followed by the same letters in the same column are not significantly \\
$\quad$ different according to Duncan's multiple range test at 5\%. (-): no interaction
\end{tabular}


Table 4. Period and rate of transpiration of different accessions of moringa plants planted at different sites

\begin{tabular}{|c|c|c|c|c|c|}
\hline \multirow{2}{*}{$\begin{array}{l}\text { Observation } \\
\text { time }\end{array}$} & \multirow{2}{*}{ Variables } & \multirow{2}{*}{ Planting sites- } & \multicolumn{2}{|c|}{ Type of moringa plants } & \multirow{2}{*}{ Mean } \\
\hline & & & Green-stalked & Purple-stalked & \\
\hline \multirow{8}{*}{$\begin{array}{l}\text { September } 2016 \\
\text { (Dry season) }\end{array}$} & \multirow{4}{*}{$\begin{array}{l}\text { Period of transpiration } \\
\left(\text { second. } \mathrm{cm}^{-2}\right)\end{array}$} & Bluto & 177.80 & 180.60 & $179.20 \mathrm{a}$ \\
\hline & & Guluk-guluk & 162.00 & 148.40 & $155.20 \mathrm{a}$ \\
\hline & & Mean & $169.90 p$ & $164.50 p$ & \\
\hline & & CV (\%) & 19.33 & & $(-)$ \\
\hline & \multirow{4}{*}{$\begin{array}{l}\text { Rate of transpiration } \\
\text { (g.dm }{ }^{-2} \text { per second) }\end{array}$} & Bluto & 20.50 & 20.38 & $20.44 a$ \\
\hline & & Guluk-guluk & 24.00 & 26.41 & $25.21 \mathrm{a}$ \\
\hline & & Mean & $36.81 p$ & $36.82 p$ & \\
\hline & & CV (\%) & 20.33 & & $(-)$ \\
\hline \multirow{8}{*}{$\begin{array}{l}\text { February } 2017 \\
\text { (Rainy season) }\end{array}$} & \multirow{4}{*}{$\begin{array}{l}\text { Period of transpiration } \\
\left(\text { second. } \mathrm{cm}^{-2}\right)\end{array}$} & Bluto & $93.80 \mathrm{bc}$ & $120.60 \mathrm{a}$ & 107.20 \\
\hline & & Guluk-guluk & $108.00 a b$ & $83.60 \mathrm{c}$ & 95.80 \\
\hline & & Mean & 100.90 & 102.10 & \\
\hline & & CV (\%) & 15.48 & & $(+)$ \\
\hline & \multirow{4}{*}{$\begin{array}{l}\text { Rate of transpiration } \\
\text { (g.dm }{ }^{-2} \text { per second) }\end{array}$} & Bluto & $38.97 \mathrm{ab}$ & $30.34 \mathrm{c}$ & 34.66 \\
\hline & & Guluk-guluk & $34.66 \mathrm{bc}$ & $43.30 \mathrm{a}$ & 38.98 \\
\hline & & Mean & 36.81 & 36.82 & \\
\hline & & CV (\%) & 11.62 & & $(+)$ \\
\hline
\end{tabular}

Remarks: Means followed by the same letters in the same column were not significantly different according to Duncan's multiple range test at 5\%. (+): there was an interaction effect between treatment. (-): no interaction between treatment

significant difference in the period and rate of transpiration of moringa grown in Bluto and Gulukguluk. Likewise, there was no significant difference in the period and rate of transpiration between the accessions of moringa. On the contrary, in February 2017, the period and rate of transpiration of purplestalked moringa grown either in Bluto or Gulukguluk had a higher value than those of the green-stalked ones.

The environmental condition in Bluto is drier, and the purple-stalked moringa is less resistant to drought conditions. Thus, the plants respond to water shortages by reducing the transpiration rate to save water. Lack of water in the leaves will cause plant cells to lose turgor. The mechanism that can slow down the rate of transpiration or prevent the impact of the loss of water is by closing the stomata and reducing the surface area of the leaves by rolling leaves (Fischer and Fukai, 2003). Limited water conditions with lower transpiration rate or equal to the rate of water absorption by the roots resulted in the prevention of inhibited plant growth. The transpiration rate is controlled by the opening of the stomata. Under conditions of water shortage, the stomata will close, and gas exchange decreases. The ability to suppress water loss through trans-piration is one of the important factors in the tolerance of plants to lack of water.

\section{Proline}

Table 5 show that there was no interaction effect observed in September 2016, whereas there was an interaction effect between the planting sites and the accession of moringa on the proline content of moringa leaves observed in February 2017. In September 2016, the proline content of purplestalked moringa leaves planted either in Bluto or Guluk-guluk was not significantly different from that of the green-stalked ones. Meanwhile, in February 2017, purple-stalked moringa leaves planted in Bluto had the highest proline content. Conversely, purple-stalked moringa leaves planted in Gulukguluk had the lowest proline content.

This result was because, in September 2016, the planting sites experienced drought so that the proline content tended to be higher than in February 2017. 
Table 5. Proline content of moringa leaves of different moringa accessions planted at different planting sites

\begin{tabular}{|c|c|c|c|c|}
\hline \multirow{2}{*}{$\begin{array}{l}\text { Observation } \\
\text { time }\end{array}$} & \multirow{2}{*}{ Planting sites - } & \multicolumn{2}{|c|}{$\begin{array}{l}\text { Proline content } \\
\left(\mu \mathrm{mol} . \mathrm{g}^{-1}\right)\end{array}$} & \multirow{2}{*}{ Mean } \\
\hline & & Green-stalked & Purple-stalked & \\
\hline \multirow{4}{*}{$\begin{array}{l}\text { September } 2016 \\
\text { (Dry season) }\end{array}$} & Bluto & 35.87 & 34.06 & $35.14 a$ \\
\hline & Guluk-guluk & 42.57 & 31.69 & $37.27 \mathrm{a}$ \\
\hline & Mean & $39.36 p$ & $33.05 p$ & \\
\hline & CV (\%) & 17.84 & & $(-)$ \\
\hline \multirow{4}{*}{$\begin{array}{l}\text { February } 2017 \\
\text { (Rainy season) }\end{array}$} & Bluto & $5.71 \mathrm{ab}$ & $8.12 \mathrm{a}$ & 6.24 \\
\hline & Guluk-guluk & $6.76 \mathrm{ab}$ & $4.56 \mathrm{~b}$ & 5.66 \\
\hline & Mean & 6.24 & 6.34 & \\
\hline & CV (\%) & 27.66 & & $(+)$ \\
\hline
\end{tabular}

Remarks: Means followed by the same letters in the same column were not significantly different according to Duncan's multiple range test at $5 \%$. (+): there was an interaction effect between treatment. (-): no interaction between treatment

Table 6. The relative moisture content of different accessions of moringa leaves planted at different planting sites

\begin{tabular}{|c|c|c|}
\hline \multirow[b]{2}{*}{ Treatment } & \multicolumn{2}{|c|}{ Relative moisture content (\%) } \\
\hline & $\begin{array}{c}\text { September } 2016 \\
\text { (Dry season) }\end{array}$ & $\begin{array}{l}\text { February } 2017 \\
\text { (Rainy season) }\end{array}$ \\
\hline \multicolumn{3}{|l|}{ Planting sites } \\
\hline Bluto & $48 \mathrm{a}$ & $54 \mathrm{a}$ \\
\hline Guluk-guluk & 49 a & 39 a \\
\hline \multicolumn{3}{|l|}{ Stalk color } \\
\hline Green & $49 p$ & $49 p$ \\
\hline Purple & $48 \mathrm{p}$ & $44 p$ \\
\hline CV (\%) & 14.01 & 18.09 \\
\hline Interaction & $(-)$ & $(-)$ \\
\hline
\end{tabular}

Plants experiencing drought stress will accumulate compounds that play a role in osmotic adjustment. Proline is a metabolite that can be used as an indicator of drought resistance (Lakitan, 2018). Plants under drought conditions will inhibit proline oxidation, thereby increasing the concentration in plants. In line with the opinion of Maestri et al. (1995), the proline content in the roots would increase if the plant experiences drought stress.

\section{Relative moisture content}

There was no interaction effect between the planting sites and the accessions of moringa plants on the relative moisture content of moringa leaves observed in September 2016 and February 2017 (Table 6). The single factor, either the planting sites or the accessions of moringa, did not give significant effect on the relative moisture content of moringa leaves.

Mahalleh et al. (2011) reported that moisture content was relatively influenced by season and irrigation, so that drought stress can significantly reduce the value of moisture content. However, the result of this research showed that in the dry and rainy season, the relative moisture content values were almost the same, presumably because the rate 
Table 7. Nitrate Reductase Activity (NRA) content of different accessions of moringa leaves planted at different sites

\begin{tabular}{|c|c|c|c|c|}
\hline \multirow{2}{*}{$\begin{array}{l}\text { Observation } \\
\text { time }\end{array}$} & \multirow{2}{*}{ Planting sites } & \multicolumn{2}{|c|}{ NRA $\left(\mu \mathrm{mol} \mathrm{NO}^{2-} \mathrm{g}^{-1} \cdot \mathrm{h}^{-1}\right)$} & \multirow{2}{*}{ Mean } \\
\hline & & Green-stalked & Purple-stalked & \\
\hline \multirow{4}{*}{$\begin{array}{l}\text { September } 2016 \\
\text { (Dry season) }\end{array}$} & Bluto & $1.37 \mathrm{~b}$ & $1.44 \mathrm{~b}$ & 1.40 \\
\hline & Guluk-guluk & $2.12 \mathrm{a}$ & $1.51 \mathrm{~b}$ & 1.82 \\
\hline & Mean & 1.75 & 1.47 & \\
\hline & CV (\%) & 16.77 & & $(+)$ \\
\hline \multirow{4}{*}{$\begin{array}{l}\text { February } 2017 \\
\text { (Rainy season) }\end{array}$} & Bluto & 0.92 & 2.05 & $1.88 \mathrm{a}$ \\
\hline & Guluk-guluk & 1.09 & 2.49 & $1.79 \mathrm{a}$ \\
\hline & Mean & $1.01 \mathrm{q}$ & $2.27 p$ & \\
\hline & CV (\%) & 18.09 & & $(-)$ \\
\hline
\end{tabular}

of water loss by leaves was almost the same as the absorption of water by plants, resulting in the same moisture content. The relative moisture content as an indicator of plant water status is related to the ability of plants to absorb water and maintain it in the leaf cells. The high relative moisture content is a mechanism of plant resistance to drought, and high relative water content is the result of excessive osmotic regulation or reduction in the elasticity of cell wall tissue.

\section{Nitrate Reductase Activity (NRA)}

Data in Table 7 show that there was an interaction effect between the planting sites and the accessions of moringa on the NRA content of moringa leaves observed in September 2016, and there was no interaction observed in February 2017. In September 2016, green-stalked moringa leaves planted in Guluk-guluk had the highest NRA content compared to other treatments. Meanwhile, the other treatments had no significant effects on NRA content. In February 2017, moringa leaves planted either in Bluto and Guluk-guluk had NRA content values that were not significantly different. Whereas, the content of NRA of green-stalked moringa leaves was lower than that of red-stalked ones. However, when planted in Bluto under severe drought stress, $13 \%$ moisture approaching the permanent wilting of green moringa which was more resistant to drought was no longer able to cope with the negative effects of drought.
This result is because the NRA content decreases in plants experiencing drought stress. The reduction in NRA content can be related to a decrease in nitrate translocation in the xylem. The decrease of NRA in plants occurs under drought condition. Low NRA content causes a small amount of nitrite to be converted into ammonium. If the ammonium produced is small, it will automatically decrease the levels of amino acids formed. The decrease affects the level of protein produced (Salisbury and Ross, 1995), so that it also affects the production, which can ultimately reduce crop yields. Brandao and Sodek (2009) stated that reduced nutrient uptake of nitrogen from the soil caused a decrease in the movement of nitrate to leaves, which resulted in low nitrate reductase activity.

\section{CONCLUSIONS}

The green-stalked moringa plants planted in Guluk-guluk showed higher Nitrate Reductase Activity in September (dry season). Purple-stalked moringa plants planted in Bluto had the longest transpiration period, higher proline content in February (rainy season). Moringa plants planted in Guluk-guluk had higher stomatal density than those planted in Bluto. The green-stalked moringa plants performed wider stomata opening compared to the purple-stalked ones, while NRA content in green-stalked moringa plants was lower than on the purple-stalked ones. 


\section{ACKNOWLEDGMENT}

The authors would like to thank the BPPDN for financial support for this study.

\section{REFERENCES}

Akunda, E., M. W. Akunda, and D. Kumar. 1981. A simple technique for timing irrigation in coffee using cobalt chloride paper disks. Irrigation Science, 3 : 57-62.

Anni, I. A, E. Saptiningsih, and S. Haryanti. 2013. Pengaruh naungan terhadap pertumbuhan dan produksi tanaman bawang daun (Allium fistulosum L.) di Bandungan, Jawa Tengah. Jurnal Biologi, 2 : 31-40.

Badan Pusat Statistik Kabupaten Sumenep. 2014. Sumenep dalam angka 2014. https:// sumenepkab.bps.go.id/publication.htm/?

Barselia, A. W., M. Yasir, E. H. Prameisti, Y. Permanasari, H. L. Rizkia, N. L. P. S. Dewi, D. R. Sinaga, W. Busse, S. Ulbricht, M. P. Koentjoro, and E. N. Prasetyo. 2014. Integrated study of Moringa oleifera as high potential commodity in the small island: A case study. Poteran Island, Sumenep. SIDI ITS Surabaya. Matec ITS, 1-9.

Bates, L. S., R. P. Waldren, and I. D. Teare. 1973. Rapid determination of free proline for water stress studies. Plant and Soil Journal, 39: 205-207.

Brandao, A. D. and L. Sodek. 2009. Nitrate uptake and metabolism by roots of soybean plants under oxygen deficiency. Brazilian Society of Plant Physiology, 21: 13-23.

Chumark, P., P. Khunawat, Y. Sanvarinda, S. Phonrnchirasilp, P.N. Morales, L. Phivtong-ngam, P. Ratanachanong, S. Srisawat, and K.S. Pongrapeporn. 2008. The in vitro and ex vivo antioxidant properties, hypolipidaemic and antiaherosleroticactivities of water extract Moringa oleifera Lamk leaves. Journal of Ethnopharmacology, 116: 439-446.

Fischer, K. S. and S. Fukai. 2003. How rice responds to drought. Breeding rice for the droughtprone environment. $1^{\text {st }}$ ed. Philippines : IRRI.

Haryanti, S. 2010. Jumlah dan distribusi stomata pada daun beberapa spesies tanaman dikotil dan monokotil. Buletin Anatomi dan Fisiologi, 13: 21-28.
Herrera A, M. D. Fernandez, and M. D. Taisma. 2000. Effect of drought and water relations in plant of Peperomia carnevalii. Annals of Botany, 86: 511-517.

Islami, T. and W. H. Utomo. 1995. Hubungan tanah, air dan tanaman. $1^{\text {st }}$ ed. Semarang : IKIP Semarang Press.

Khaerana, M. Ghulamahdi, and E. D. Purwakusumah. 2008. Pengaruh cekaman kekeringan dan umur panen terhadap pertumbuhan dan kandungan xanthorrhizol temulawak (Curcuma xanthorrhiza roxb .). Buletin Agronomi, 3: 241-247.

Lakitan, B. 2018. Dasar-dasar fisiologi tumbuhan. $8^{\text {th }}$ ed. Jakarta : PT. Raja Grafindo Persada.

Liu, F., Jensen, and M. N. Andersen. 2004. Drought stress effect on carbohydrate in soybeans leaves and pods during early reproductive development: its implication in altering pod set. Field Crop Research, $86: 1-13$.

Luthfiyah, F. 2012. Potensi gizi daun kelor (Moringa oleifera) Nusa Tenggara Barat. Media Bina Ilmiah, $6: 42-50$.

Maestri, M. F. M. Da Matta, J. Regazzi, and R.S. Barros. 1995. Accumulation of proline and quaternary ammonium compounds in mature leaves of water stressed coffea plants (Coffea arabica and C. Canephora). Journal of Horticultural Science, 70: 229-233.

Mahalleh, J. K., H. H. S. Abad, G. Nourmohammadi, F. Darvish, I. M. Haravan, and E. Valizadegan. 2011. Effect of super absorbent polymer (Tarawat A200) on forage yield and qualitative characters in corn under deficit irrigation condition in Khoy Zone (Northwest of Iran). Advances in Environmental Biology, 5: 2579_ 2587.

Novenda, I. L. and S. A. Nugroho. 2016. Analisis kandungan prolin tanaman kangkung (Ipomoea Reptana Poir), bayam (Amaranthus Spinosus), dan ketimun (Cucumis Sativus L.). Pancaran, 5: 223-234.

Salisbury, F. B. and C. W. Ross. 1995. Fisiologi tumbuhan. $1^{\text {st }}$ ed. Bandung : Penerbit ITB. 